\title{
Tolerance of different dairy products in subjects with symptomatic lactose malabsorption due to adult type hypolactasia
}

\author{
Tolerancja różnych produktów mlecznych u osób z objawowym zespołem złego \\ wchłaniania laktozy spowodowanym hipolaktazją typu dorosłych
}

\author{
Edyta Mądry¹, Beata Krasińska², Małgorzata Woźniewicz³, Sławomira Drzymała-Czyż, Waldemar Bobkowski \\ Teresa Torlińska1, Jarosław Walkowiak ${ }^{3,4}$ \\ 1Department of Physiology, Poznan University of Medical Sciences, Poland \\ 2Department of Hypertension, Angiology and Internal Medicine, Poznan University of Medical Sciences, Poland \\ 3Department of Dietetics, Chair of Human Nutrition and Hygiene, Poznan University of Life Sciences, Poland \\ 4Department of Paediatric Gastroenterology and Metabolism, 1st Chair of Paediatrics, Poznan University of Medical Sciences, \\ Poland \\ 5Department of Paediatric Cardiology and Nephrology, $1^{\text {st }}$ Chair of Paediatrics, Poznan University of Medical Sciences, Poland
}

Przegląd Gastroenterologiczny 2011; 6 (5): 310-315

DOI: $10.5114 /$ pg.2011.25381

Key words: lactose malabsorption, lactose intolerance, adult type hypolactasia, yogurt, kefir.

Słowa kluczowe: zespół złego wchłaniania laktozy, nietolerancja laktozy, hipolaktazja typu dorosłych, jogurt, kefir.

Address for correspondence: Prof. Jarosław Walkowiak MD, PhD, Department of Paediatric Gastroenterology and Metabolism, $1^{\text {st }}$ Chair of Paediatrics, Poznan University of Medical Sciences, 27/33 Szpitalna, 60-572 Poznan, Poland, tel.: +48 6184803 10, e-mail: jarwalk@ump.edu.pl

\begin{abstract}
Introduction: A large portion of the world's population undergoes a genetically programmed decrease in lactase synthesis and may experience symptoms of lactose intolerance (LI) after dairy consumption.

Aim: The aim of the present study was to assess the effect of the same dose of lactose consumed by LI subjects in the form of different dairy products.

Material and methods: Fifteen healthy young adults with $\mathrm{LI}$ were enrolled in the study. All subjects were symptomatic homozygotes $-13910 \mathrm{C} / \mathrm{C}$ in the lactase promoter gene. The hydrogen-methane breath test was performed in each subject after a load of $400 \mathrm{ml}$ of milk, kefir and yogurt. Clinical symptoms were assessed within the $12 \mathrm{~h}$ after each product consumption.

Results: The excretion of gases was lower after ingestion of kefir and yogurt in comparison to milk. All examined subjects reported symptoms. After milk consumption, abdominal pain and intestinal rumbling were perceived as more severe. The number of stools was higher and their consistency was more liquid.

Conclusions: Young adults with $\mathrm{LI}$ are not able to tolerate the typical dose of different dairy products as assessed by subjective and objective measures. The tolerance of kefir and yogurt is significantly better than that of milk.
\end{abstract}

\section{Streszczenie}

Wstęp: U znacznej części ludności świata produkcja laktazy podlega genetycznie zaprogramowanej redukcji, co może prowadzić do występowania objawów klinicznych nietolerancji laktozy (NL) po spożyciu produktów mlecznych.

Cel: Ocena wpływu spożycia takiej samej dawki laktozy przez osoby z NL, podawanej w postaci różnych produktów mlecznych.

Materiał i metody: Badaniem objęto 15 młodych dorosłych z objawową NL. Wszyscy badani byli homozygotami -13910 C/C w zakresie genu promotorowego dla laktazy. U każdej osoby wykonano wodorowo-metanowy test oddechowy po obciążeniu $400 \mathrm{ml}$ mleka, kefiru i jogurtu. Objawy kliniczne oceniano przez 12 godz. po spożyciu każdego produktu.

Wyniki: Wydalanie gazów było mniejsze po spożyciu kefiru i jogurtu niż mleka. Wszyscy badani zgłaszali objawy kliniczne. Po spożyciu mleka bóle brzucha i przelewania były bardziej nasilone, stwierdzono większą liczbę stolców, a ich konsystencja była bardziej płynna.

Wnioski: Młodzi dorośli z NL nie tolerują typowych porcji produktów mlecznych, co potwierdzono w ocenie subiektywnej i obiektywnej. Tolerancja kefiru i jogurtu jest znacząco lepsza niż mleka. 


\section{Introduction}

Lactose malabsorption is caused by a decrease in the ability to digest lactose, which is due to a deficiency in the level of lactase (LCT [MIM 603202]). This enzyme, which is necessary for the digestion of lactose, the major carbohydrate in milk, is produced by the expression of the lactase-phlorizin hydrolase gene in the cells lining the small intestine [1]. In the case of decreased LCT activity (hypolactasia), milk consumption can lead to symptoms of lactose intolerance (LI) such as bloating, flatulence, cramps, nausea and diarrhoea, and may contribute to the decision to exclude these products from the diet [2,3]. A large portion of the world's population undergoes a genetically programmed decrease in LCT synthesis after weaning, which may result in lactose malabsorption $[4,5]$. The condition known as adult-type hypolactasia (ATH) is the most common cause of milk intolerance in children, adolescents and adults and the most common enzyme deficiency in humans [6]. Although it has been documented in recent years that a much smaller percentage of individuals with lactose maldigestion develops clinical symptoms [7-9], the issue remains of particular nutritional importance because dairy products are a major source of calcium, vitamin $D$ and other nutrients. In LI individuals, the amounts of these essential nutrients supplied by a diet lacking dairy products may be insufficient to meet the age-appropriate adequate intake [10], as was found in a majority of African American adolescents [11].

One of the strategies in the treatment of $\mathrm{LI}$ is to restrict consumption of dairy products; however, such a diet usually contains less calcium than the recommended daily intake. Another approach is the consumption of a diet containing lactose, but only incorporating those products that are better tolerated and/or in quantities that do not cause clinical symptoms. The use of fermented dairy products has long been adopted as a strategy for overcoming LI [12-14]. However, evidence for the efficacy of such an approach is insufficient. Therefore, the aim of the present study was to assess the effect of the same dose of lactose consumed in the form of different dairy products - kefir, yogurt and milk - by lactose-intolerant young healthy adults.

\section{Material and methods}

Fifteen highly motivated, clinically symptomatic, otherwise healthy young adults with $\mathrm{LI}$ were enrolled in the study. The investigated group consisted of 8 women and 7 men, all of Caucasian descent, aged 20-25 years (mean 22.7 years) with body mass index (BMI) ranging from 19 to $25 \mathrm{~kg} / \mathrm{m}^{2}$ (mean $21.5 \mathrm{~kg} / \mathrm{m}^{2}$ ). All of the enrol- led participants reported symptoms indicative of lactose intolerance prior to the study.

A predisposition to ATH was confirmed by molecular analysis; all subjects were homozygotes $\mathrm{C} / \mathrm{C}$ at locus $13910(-13910 \mathrm{C} / \mathrm{C})$ upstream of the LCT gene (NM_005915.4:c.1917+326C>T; rs4988235). For -13910 $\mathrm{T}>\mathrm{C}$ polymorphism detection the kit MutaGEL Lactase (Immundiagnostik AG, Bensheim, Germany) was used. The details of applied methodology have been described elsewhere [9].

Lactose malabsorption (LM) was confirmed in all study participants based on a hydrogen-methane breath test (BT) with a load of $25 \mathrm{~g}$ of lactose, following an overnight fast. More specifically, subjects were instructed not to eat or drink for at least $12 \mathrm{~h}$ before the test and to avoid slowly digested foods, including beans and other legumes, brans or high-fibre cereals, on the day before the test. Participants were not allowed to smoke, sleep or exercise vigorously for at last $1 \mathrm{~h}$ before or at any time during the test. Breath samples were collected at baseline (fasting) and every 30 min within the $3 \mathrm{~h}$ after the ingestion of lactose. The samples were analysed with QuinTron MicroLyser DP Plus (Quintron, USA). A positive $B T$ was defined as a breath $\mathrm{H}_{2}$ level increase of at least $20 \mathrm{ppm}$ over the lowest preceding value within the test period or a breath $\mathrm{CH}_{4}$ level increase of at least $12 \mathrm{ppm}$ over the baseline within the test period, or as a combined increase $\left(\mathrm{H}_{2}\right.$ and $\left.\mathrm{CH}_{4}\right)$ of at least $15 \mathrm{ppm}$ within the test period.

After selection of the study group a BT was performed three times in each of the subjects (intervals of at least 7 days) after the load of $400 \mathrm{ml}$ of milk, kefir and yogurt given as a single serving to be drank (lactose content $19.2 \mathrm{~g}, 18.4 \mathrm{~g}$ and $19.2 \mathrm{~g}$, respectively). Breath samples were collected at baseline (fasting) and 30, 60, $90,120,150,180,210,240,270$ and 300 min after lactose-containing product ingestion. The excretion of gases was expressed as the sum of hydrogen and doubled methane expiration.

Clinical symptoms were assessed within the $12 \mathrm{~h}$ after each product load using the questionnaire adopted for the project. The following issues were addressed:

1) abdominal pain ( 0 - abdominal pain did not occur/1 discomfort/2 - mild pain/3 - pain impeding the normal functioning/4 - unbearable pain),

2) number of stools ( 0 - no stool/1, 2, 3... - corresponded to the number of stools),

3) stool consistency ( 0 - formed/1 - mushy or compressed/2 - loose/3 - liquid),

4) intestinal rumbling ( 0 - lack/1 - barely perceptible/2 moderately severe/3 - very severe).

In addition, the BT area under the curve (AUC) was calculated assuming that it reflects semi-quantitatively 
the total amount of intestinal gas production over the $5-\mathrm{h}$ period. All values are expressed as median $\left(1^{\text {st }}-3^{\text {rd }}\right.$ quartile).

Statistical analysis of the data was performed using the Kruskal-Wallis test with post-hoc comparisons.

\section{Ethical considerations}

The protocol of the investigation was approved by the Ethical Committee of the Poznan University of Medical Sciences, Poland (150/11). Written informed consent was obtained from all subjects.

\section{Results}

The comprehensive data of BT after loading with milk, kefir and yogurt are shown in Table I. Thirteen subjects exhaled exclusively hydrogen, while in two individuals the excretion of methane was also observed. There were no significant differences in the fasting breath hydrogen/methane levels among the three products. The excretion of gases appeared to be lower after ingestion of kefir and yogurt in comparison to milk. Statistically significant differences did occur from the 60 up to 240 min period of the study. However, the yogurt and the kefir consumption caused peaks that occurred a little bit later than did milk ingestion (180 min vs. 240 min after loading). The value of hydrogen/methane AUC for milk [284.5 ppm h (230.3-371.5)] was significantly higher than for kefir [152.5 ppm h (134.5-205.5)] and yogurt [185.0 ppm h (153.5-196.8)]; ( $p<0.007$ for both). There were no differences in AUC between fermented products.

All examined subjects reported symptoms after ingesting $400 \mathrm{ml}$ of milk, kefir and yogurt. However, milk consumption resulted in more severe symptoms. Abdominal pain and intestinal rumbling were perceived as more severe. The number of stools was higher and their consistency was more liquid. No differences in the perception of clinical symptoms between kefir and yogurt loading were reported (Table II).

\section{Discussion}

The strongest argument for the consumption of dairy products by $\mathrm{LI}$ individuals is the beneficial effect of calcium and vitamin D present in milk on skeletal growth and development. In the absence of guidelines for LI subjects, the common therapeutic approach invoIves the exclusion of milk and dairy products from the diet. An insufficient vitamin D and calcium intake can lead to poor health outcomes, particularly in relation to bone mineral density and the risk of fractures $[15,16]$. The determination of whether fermented dairy products can be better tolerated than milk may contribute to the development of evidence-based dietary recommendations that meet the needs of $\mathrm{LI}$ individuals.

The enrolment criteria seem to be one of the major limiting factors in the existing studies on hypolactasia. Subjects who are evaluated in such studies often present LM rather than $\mathrm{LI}$ [17]. The term $\mathrm{LI}$ indicates that

Table I. Hydrogen-methane breath test (ppm) in relation to ingestion of $400 \mathrm{ml}$ of milk, kefir and yogurt in 15 lactose-intolerant subjects

Tabela l. Wyniki wodorowo-metanowego testu oddechowego po spożyciu $400 \mathrm{ml} \mathrm{mleka,} \mathrm{kefiru} \mathrm{i} \mathrm{jogurtu}$ przez 15 osób z nietolerancja laktozy

\begin{tabular}{|c|c|c|c|c|c|c|c|c|c|c|c|c|}
\hline \multirow[t]{2}{*}{ Product } & \multicolumn{12}{|c|}{ Time [min] } \\
\hline & & 0 & 30 & 60 & 90 & 120 & 150 & 180 & 210 & 240 & 270 & 300 \\
\hline \multirow[t]{2}{*}{ Milk } & Median & 0 & 1 & 5 & 18 & 39 & 49 & 57 & 52 & 44 & 33 & 27 \\
\hline & $\begin{array}{l}1^{\text {st. }} 3^{\text {rd }} \\
\text { quartile }\end{array}$ & $0-3$ & $0-4$ & $2.5-8.5$ & $9.5-21.5$ & $22-46$ & $38.5-62$ & $39-66$ & $40.5-63.5$ & $36.5-57.5$ & $28-42.5$ & $22-29$ \\
\hline \multirow[t]{2}{*}{ Kefir } & Median & 0 & 1 & 2 & 8 & 14 & 23 & 26 & 28 & 31 & 31 & 26 \\
\hline & $\begin{array}{l}1^{\text {st.-3rd }} \\
\text { quartile }\end{array}$ & $0-3.5$ & $0-2.5$ & $0.5-4$ & $6-10.5$ & $11-22$ & $17-26$ & $20-33.5$ & $23-37.5$ & $26.5-35$ & $24.5-35$ & $22-32$ \\
\hline \multirow[t]{2}{*}{ Yogurt } & Median & 0 & 0 & 1 & 7 & 15 & 21 & 26 & 32 & 33 & 32 & 28 \\
\hline & $\begin{array}{l}1^{\text {st.-3rd }} \\
\text { quartile }\end{array}$ & $0-2.5$ & $0-2$ & $0-5$ & $4-8$ & $10.5-15.5$ & $17.5-24.5$ & $20.5-32$ & $24.5-35$ & $25-35.5$ & $26.5-35.5$ & $23-31.5$ \\
\hline \multicolumn{13}{|c|}{ Statistical significance } \\
\hline \multicolumn{2}{|c|}{ Milk vs. kefir } & NS & NS & 0.0079 & 0.0021 & 0.0019 & 0.0015 & 0.0012 & 0.0012 & 0.0015 & NS & NS \\
\hline \multicolumn{2}{|c|}{ Milk vs. yogurt } & NS & NS & 0.0171 & 0.0019 & 0.0022 & 0.0007 & 0.0007 & 0.0007 & 0.0007 & NS & NS \\
\hline \multicolumn{2}{|c|}{ Kefir vs. yogurt } & NS & NS & NS & NS & NS & NS & NS & NS & NS & NS & NS \\
\hline
\end{tabular}

NS - not significant 
Table II. Clinical symptoms reported in relation to ingestion of $400 \mathrm{ml}$ of milk, kefir and yogurt in 15 lactoseintolerant subjects

Tabela II. Objawy kliniczne w odniesieniu do spożycia $400 \mathrm{ml}$ mleka, kefiru i jogurtu przez 15 osób z nietolerancją laktozy

\begin{tabular}{|c|c|c|c|c|c|c|c|c|}
\hline \multirow[t]{2}{*}{ Product } & \multicolumn{2}{|c|}{ Abdominal pain } & \multicolumn{2}{|c|}{ Number of stools } & \multicolumn{2}{|c|}{ Stool consistency } & \multicolumn{2}{|c|}{ Intestinal rumbling } \\
\hline & Median & $\begin{array}{c}1^{\text {st-3rd }} \\
\text { quartile }\end{array}$ & Median & $\begin{array}{c}1^{\text {st-3rd }} \\
\text { quartile }\end{array}$ & Median & $\begin{array}{c}1^{\text {st-3rd }} \\
\text { quartile }\end{array}$ & Median & $\begin{array}{l}1^{\text {st-3rd }} \\
\text { quartile }\end{array}$ \\
\hline Milk & 2 & $2-3$ & 2 & $1.5-3$ & 2 & $1-2$ & 3 & $2.5-3$ \\
\hline Kefir & 1 & $1-2$ & 1 & 1-1 & 1 & $0.5-1$ & 2 & $1-2$ \\
\hline Yogurt & 1 & $1-1.5$ & 1 & $1-1$ & 1 & $0-1$ & 1 & $1-2$ \\
\hline \multicolumn{9}{|c|}{ Statistical significance } \\
\hline Milk vs. kefir & 0.0060 & & 0.0015 & & 0.0022 & & 0.0015 & \\
\hline Milk vs. yogurt & 0.0033 & & 0.0015 & & 0.0033 & & 0.0010 & \\
\hline Kefir vs. yogurt & NS & & NS & & NS & & NS & \\
\hline
\end{tabular}

a person with LM reports clinical symptoms after lactose consumption. Whereas lactase deficiency and LM can be objectively verified by an intestinal biopsy or a breath test, the demonstration of $\mathrm{LI}$ relies on self-reported symptoms following lactose ingestion. In the present study, a very careful pre-selection of the study group was carried out, as only LI subjects were enrolled, all of whom reported symptoms indicative of $\mathrm{LI}$ prior to the study. According to our knowledge, it is the first study on lactose intolerance in which all patients have a confirmed genetic predisposition to LM. Moreover, a hydrogen-methane rather than a hydrogen breath test was used, allowing for the exclusion of some potential false negative results [18].

Despite a number of investigations evaluating $\mathrm{LI}$ subjects, medical literature concerning the use of kefir and yogurt is scarce and does not provide sufficient evidence of their effectiveness in overcoming $\mathrm{LI}$ symptoms and in improving health outcomes. The data obtained in the present study indicate that kefir and yogurt are better tolerated than milk by LI subjects, which remains in line with the few surveys carried out regarding these products $[13,19,20]$. Bearing in mind that the calcium content in yogurt is much higher than that in milk (415 mg for plain, low-fat yogurt vs. $285 \mathrm{mg}$ for semiskimmed milk, respectively, in one cup) [21], it seems reasonable that further research on fermented dairy products is warranted, in order to provide evidencebased, ethnically/racial and age-sensitive evidence.

The data on the tolerance of dairy products by $\mathrm{LI}$ individuals presented by different authors are contradictory. Two reviews of the literature on the topic of $\mathrm{LI}$ (covering the years 1967-2009) have been published so far. According to the review made by Suchy et al. (2010), $50 \mathrm{~g}$ of lactose, which is equivalent to the lactose content found in 1 quart of milk, usually induced symptoms in adults with lactose malabsorption when administered as a single dose without meals, while $12 \mathrm{~g}$ of lactose, equivalent to the lactose content in 1 cup of milk, could be tolerated with no or minor symptoms [11]. The conclusion of the review by Shaukat et al. (2010) is that even a dose of $15 \mathrm{~g}$ can be tolerated [17]. These data are inconsistent with the results of the Hertzler study based on the ingestion of various doses of lactose dissolved in water. He indicated that at most $6 \mathrm{~g}$ of lactose may be tolerated by lactose maldigesters [22]. However, natural sources of lactose are better tolerated than lactose dissolved in water. The study by Hertzler and Savaiano (1996) provided the literature's most optimistic appraisal of the daily dosage of lactose that is tolerable by LI subjects. Healthy young adult subjects with self-diagnosed LI were demonstrated to be lactose malabsorbers on the basis of BT. They were fed with either sucrose or lactose for a 10-day period with a 2-day washout between a feeding of the alternate sugar. It was found that these subjects had negligible symptoms at the initiation of lactose feeding with $42 \mathrm{~g} /$ day, and that by the end of the 10-day period, they were capable of tolerating $70 \mathrm{~g}$ (approximately 1.5 quarts of milk) per day [23]. If the results of this study could be extrapolated to the entire population of $\mathrm{LI}$ individuals, LI would not represent an appreciable clinical problem, provided that lactose was routinely ingested in divided doses with meals. Unfortunately, the findings of other authors indicate that much lower doses of lactose may cause gastrointestinal distress in people with LM, even if served in divided doses during the day (12-34 g) [24-26]. In the present study, the load of $400 \mathrm{ml}$ of milk, kefir and yogurt served as a single dose without a meal provoked clinical symptoms in all of the examined subjects. However, the symptoms perceived after the load of fermented 
products were significantly lower than those caused by milk. A possible explanation of this phenomenon may be the "autodigestive" capacity of fermented dairy products stemming from their content of $\beta$-galactosidase. This enzyme, as was shown previously, survives gastric digestion and remains active in the duodenum, where it may act in lactose digestion $[27,28]$.

Surveys by Savaiano et al. (1984) and Alm (1982) have shown that up to $500 \mathrm{~g}$ of yogurt may be tolerated by lactase-deficient persons [13, 29]. In the Savaiano study, a serving of $500 \mathrm{ml}$ of yogurt (lactose content $20 \mathrm{~g}$ ) without a meal after a fasting period did not cause abdominal distress [13]. In contrast to these results, we have documented that the same product, including the same load of lactose, and served in the same manner, brought about clinical symptoms in all examined individuals. A likely explanation may be related to the enrolment criteria. Subjects who were classified by the researchers as lactose-deficient were probably lactose malabsorbers rather than LI. The differences in tolerance shown by the various studies, carried out under the same conditions, indicate the need for a clearer distinction between $L M$ and $\mathrm{LI}$, not only in research but also in the medical/dietician practice. The Alm study demonstrated the tolerance of $500 \mathrm{ml}$ of yogurt served as a single dose by lactose-deficient individuals; however, the lactose level was decreased after an 11-day storage period, to about $2.3 \mathrm{~g} / 100 \mathrm{~g}$, compared to an initial value of $4.8 \mathrm{~g} / 100 \mathrm{~g}$, giving an effective lactose load of $11.5 \mathrm{~g}$ [29].

In the present study, the lactose loads, given in the form of milk, kefir and yogurt, were comparable (19.2 g, $18.4 \mathrm{~g}$ and $19.2 \mathrm{~g}$, respectively). However, both the severity of clinical symptoms and the excretion of gases were significantly lower in the case of fermented products. Therefore, it appears that the determination of the maximum tolerated dose of lactose is impossible for all dairy products as a single category. Our findings remain consistent with the results of Savaiano et al. and Kolars et al. [13, 27]. Savaiano et al. concluded that enhanced lactose absorption and tolerance observed with yogurt feeding are not apparent when the same dose of lactose is given in the form of unfermented acidophilus milk or cultured milk. Furthermore, pasteurized yogurt, with a reduction in the inherent lactase activity by 10 -fold and a reduction in cell count by 100 -fold, still remains better tolerated by $\mathrm{LI}$ subjects than does milk [13]. Kolars showed that ingestion of $18 \mathrm{~g}$ of lactose in yogurt resulted in only about one third the hydrogen excretion as a similar load of lactose in milk or water, indicating an increased absorption of lactose in yogurt [27].

The results of the present study suggest that the maximum tolerated dose of lactose may be different for fermented products than that for milk. For this reason we suggest that the question posed by many authors $[11,17]$, which regards the maximum tolerated dose of lactose, should be replaced by a question of the maximum tolerated dose of a specific product, or alternatively the maximum tolerated dose of lactose that is ingested in a specific product. From a practical point of view, this may facilitate in educating lactose-intolerant individuals, as the labels on dairy products do not provide a description of the lactose content, while they do provide information on the volume or weight of the product itself.

\section{Conclusions}

Young adults with $\mathrm{LI}$ are not able to tolerate the typical dose of different dairy products as assessed by subjective and objective measurement. The tolerance of kefir and yogurt is significantly better than that of milk.

\section{Conflict of interest}

None declared.

\section{References}

1. Ingram CJ, Mulcare CA, Itan Y, et al. Lactose digestion and the evolutionary genetics of lactase persistence. Hum Genet 2009; 124: 579-91.

2. Heyman MB. Lactose intolerance in infants, children, and adolescents. Pediatrics 2006; 118: 1279-86.

3. Di Stefano M, Veneto G, Malservisi S, et al. Lactose malabsorption and intolerance and peak bone mass. Gastroenterology 2002; 122: 1793-9.

4. Swaggerty DL, Walling AD, Klein RM. Lactose intolerance. Am Fam Phys 2002; 65: 1845-50.

5. Sahi T. Genetics and epidemiology of adult-type hypolactasia. Scan J Gastroenterol 1994; 29: S7-20.

6. Semenza G, Auricchio S, Mantei N. Small-intestinal disaccharidases. In: The metabolic and molecular basis of inherited disease. Scriver CR (eds). McGraw-Hill, New York 2001; 1623-50.

7. Carroccio A, Montalto MG, Notarbatolo A. Lactase Deficiency Study Group. Lactose intolerance and self-reported milk intolerance. Relationship with lactose maldigestion and nutrient intake. J Am Coll Nutr 1998; 17: 631-6.

8. Suarez FL, Savaiano DA, Levitt MD. A comparison of symptoms after the consumption of milk or lactose-hydrolyzed milk by people with self-reported severe lactose intolerance. $N$ Engl J Med 1995; 333: 1-4.

9. Mądry E, Lisowska A, Kwiecień J, et al. Adult-type hypolactasia and lactose malabsorption in Poland. Acta Biochim Pol 2010; 57: 585-8.

10. Lovelace HY, Barr SI. Diagnosis, symptoms, and calcium intakes of individuals with self-reported lactose intolerance. J Am Coll Nutr 2005; 24: 51-7.

11. Suchy FJ, Brannon PM, Carpenter TO, et al. National Institutes of Health Consensus Development Conference: lactose intolerance and health. Ann Intern Med 2010; 152: 792-6. 
12. Pelletier $X$, Laure-Boussuge S, Donazzolo Y. Hydrogen excretion upon ingestion of dairy products in lactose-intolerant male subjects: importance of the live flora. Eur J Clin Nutr 2001; 55 : 509-12.

13. Savaiano DA, AbouElAnouar A, Smith DE, et al. Lactose malabsorption from yogurt, pasteurized yogurt, sweet acidophilus milk, and cultured milk in lactase-deficient individuals. Am J Clin Nutr 1984; 40: 1219-23.

14. Hertzler SR, Clancy SM. Kefir improves lactose digestion and tolerance in adults with lactose maldigestion. J Am Diet Assoc 2003; 103: 582-7.

15. Di Stefano M, Veneto G, Malservisi S, et al. Lactose malabsorption and intolerance in the elderly. Scand J Gastroenterol 2001; 36: 1274-8.

16. Enattah N, Pekkarinen T, Välimäki MJ, et al. Genetically defined adult-type hypolactasia and self-reported lactose intolerance as risk factors of osteoporosis in Finnish postmenopausal women. Eur J Clin Nutr 2005; 59: 1105-11.

17. Shaukat A, Levitt MD, Taylor BC, et al. Systematic review: effective management strategies for lactose intolerance. Ann Intern Med 2010; 152: 797-803.

18. Lisowska A, Wójtowicz J, Walkowiak J. Small intestine bacterial overgrowth is frequent in cystic fibrosis: combined hydrogen and methane measurements are required for its detection. Acta Biochim Pol 2009; 56: 631-4.

19. Lerebours E, N'Djitoyap Ndam C, Lavoine A, et al. Yogurt and fermented-then-pasteurized milk: effects of short-term and long-term ingestion on lactose absorption and mucosal lactase activity in lactase-deficient subjects. Am J Clin Nutr 1989; 49: 823-7.

20. Martini MC, Smith DE, Savaiano DA. Lactose digestion from flavored and frozen yogurts, ice milk, and ice cream by lactase-deficient persons. Am J Clin Nutr 1987; 46: 636-40.

21. USDA National Nutrient Database for Standard Reference, Release 21; http://www.nal.usda.gov/fnic/foodcomp/Data/SR21/ nutrlist/sr21w301.pdf (Accessed 10 Apr 2011).

22. Hertzler SR, Huynh BC, Savaiano D. How much lactose is low lactose? J Am Diet Assoc 1996; 96: 243-6.

23. Hertzler SR, Savaiano DA. Colonic adaptation to daily lactose feeding in lactose maldigesters reduces lactose intolerance. Am J Clin Nutr 1996; 64: 232-6.

24. Newcomer AD, McGill DB, Thomas PJ, et al. Tolerance to lactose among lactase-deficient American Indians. Gastroenterology 1978; 74: 44-6.

25. Johnson AO, Semenya JG, Buchowski MS, et al. Adaptation of lactose maldigesters to continued milk intakes. Am J Clin Nutr 1993; 58: 879-81.

26. Briet F, Pochart P, Marteau P, et al. Improved clinical tolerance to chronic lactose ingestion in subjects with lactose intolerance: a placebo effect? Gut 1997; 41: 632-5.

27. Kolars JC, Levitt MD, Aouji M, et al. Yogurt-an autodigesting source of lactose. N Engl J Med 1984; 310: 1-3.

28. Martini MC, Kukielka D, Savaiano DA. Lactose digestion from yogurt: influence of a meal and additional lactose. Am J Clin Nutr 1991; 53: 1253-8.

29. Alm L. Effect of fermentation on lactose, glucose, and galactose content in milk and suitability of fermented milk products for lactose intolerant individuals. J Dairy Sci 1982; 65: 346-52. 